\title{
Iron Machine Sales Data Processing At Pt. Multiuser-Based Panca Teknik Banjarmasin
}

\section{Distan Madani}

Program Studi Teknik Informatika, Fakultas Teknologi Informasi, Universitas Islam Kalimantan Muhammad Al Banjari, Banjarmasin

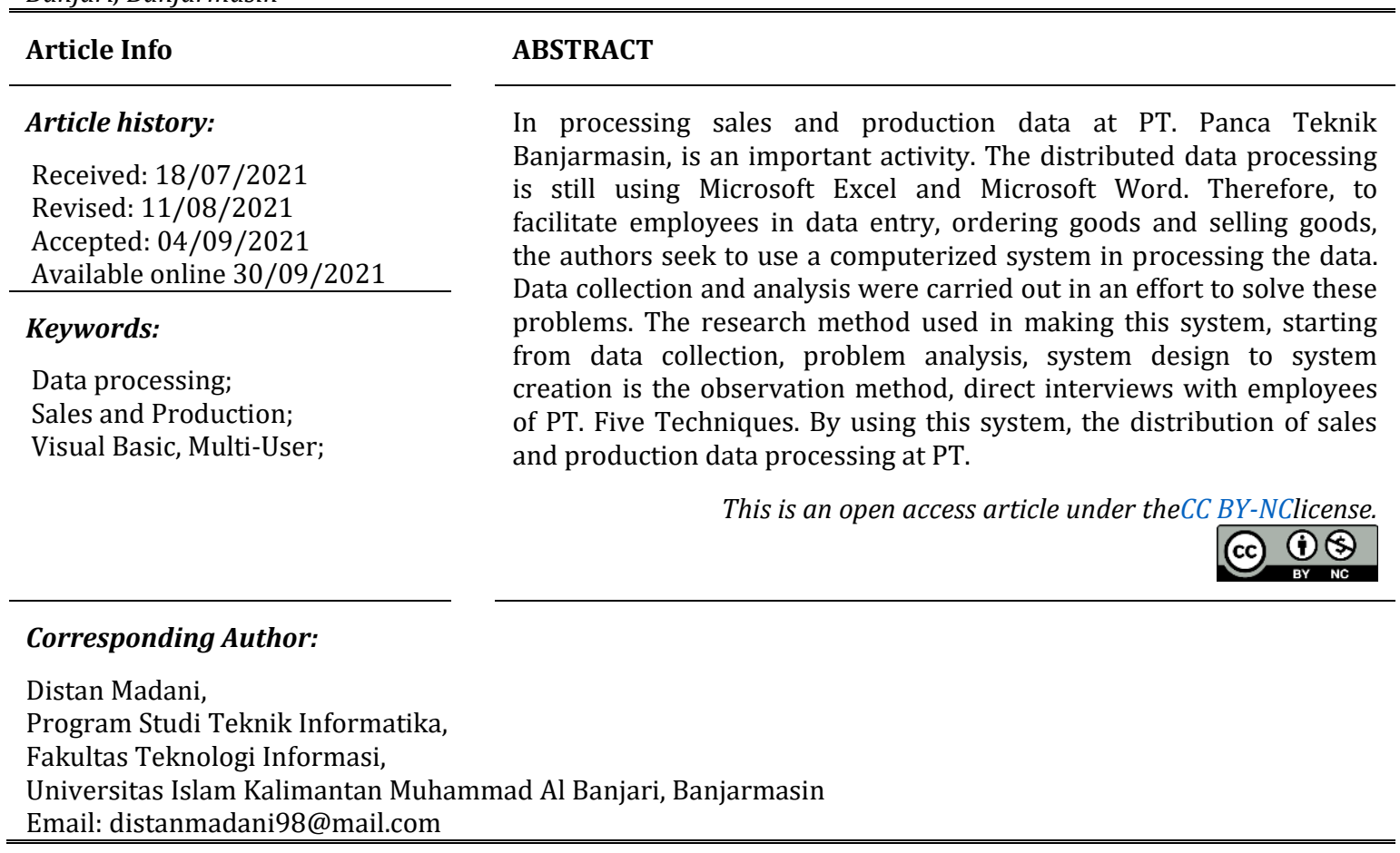

\section{Introduction}

PT. Panca Tehnik Banjarmasin, is one of the companies engaged in the sale, production of machine tools and machine repair. The items sold include iron, bolts and other machine tools. PT. Panca Teknik Banjarmasin has approximately 75 employees. This company serves private companies in South, Central, East Kalimantan. In addition, there are also customers who are not from the company, namely individuals(Octavianti \& Rahmawati, 2018).

There are so many things related to work that should have used a computerized system in data management(Syahputra, 2015). In the management of data entry and stock of goods at PT. Panca Teknik Banjarmasin must be carried out professionally so that there are no errors in the data collection itself(Maykiyah, 2019).

Sales and production data processing is an important activity. In processing distributed data, it still uses a simple program, namely using Microsoft Excel and Microsoft Word(Hendrayana, 2015). With this simple system, processing sales and production data is difficult.

\section{Method}

\subsection{Method of collecting data}

The data collection method used in the preparation of this thesis is as follows:

a. Literature Study 
Literature study is to raise and develop research problems with concepts, research results, and documentation results that have existed before. This method focuses on finding facts as they actually are(Rahardjo, 2017).Literature research seeks and integrates all existing materials related to the topic of the problem, by revealing the theoretical, conceptual, logical basis and research results as well as other secondary data. In this study, the authors conducted a literature study by reading the literature that supports the process of making system designs such as books on information systems and database design and other supporting books in the manufacture of information systems.

b. Observation

Observation is a data collection tool that is carried out by observing and systematically recording the symptoms being investigated. With a simpler description, observation can be interpreted as direct observation of an activity that is being carried out. In this study, observations were made by making direct observations at PT. Panca Tehnik Banjarmasin, namely by collecting data by looking directly at the existing information system.

c. Interview

Interview is a data collection technique with systematic question and answer and face to face (direct). Interviews can also be conducted indirectly by telephone but this is not a pure interview. Interviews are intended to obtain materials or information that we need obtained by other techniques.The aim is to gather information and not to change or influence the opinion of the respondent. An interview is a process of interaction and communication in which a number of variables play an important role because it is possible to influence and

\subsection{Research stages} determine the outcome of the interview.

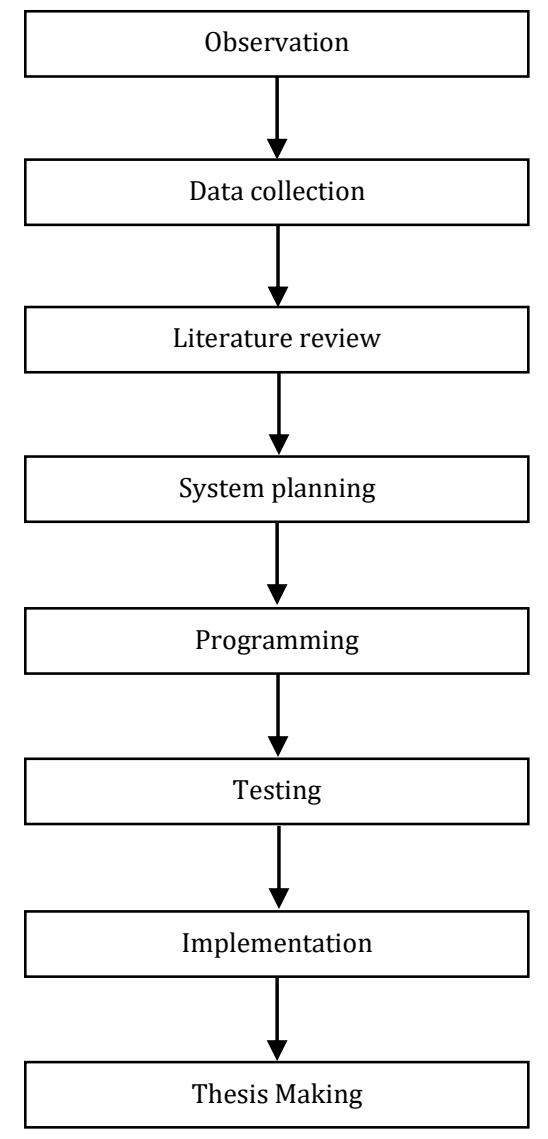

Figure 1. Research Stages 


\section{Results and Discussion}

\subsection{System Implementation}

a. Program Explanation

Start the program call by opening the PT folder. Panca Teknik double clicked, then the sales file appeared and then double clicked. The login menu display can be seen in the picture:

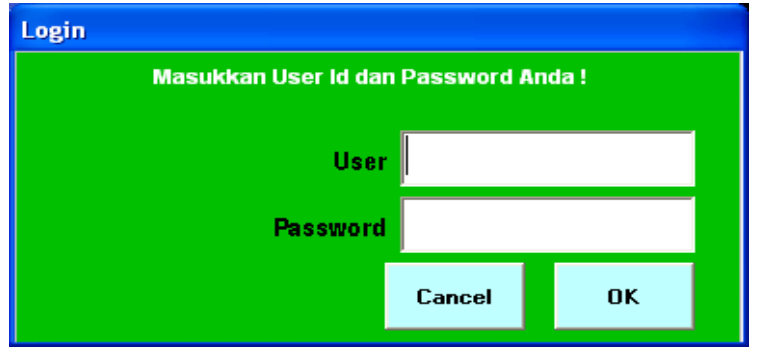

Figure 1. Login menu

If the user name and password entered are correct, the Main Menu Display will appear as follows:

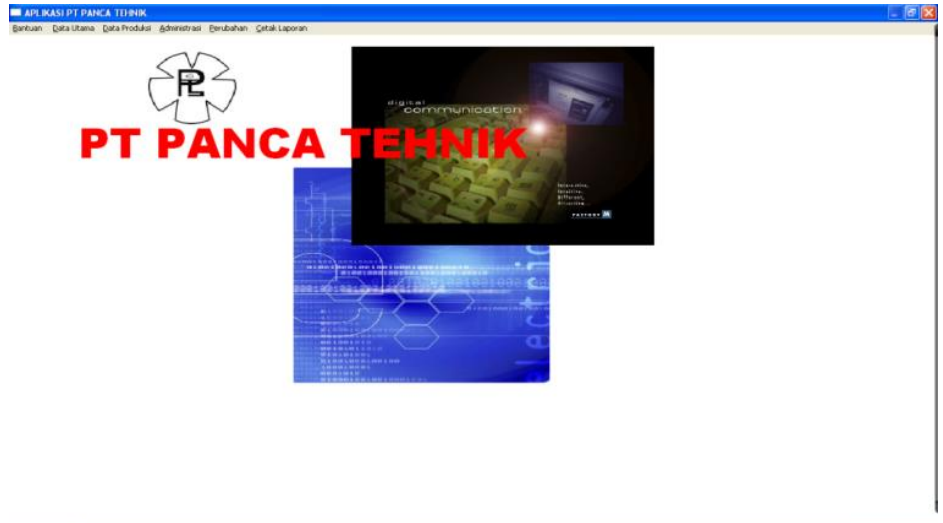

Figure 2. Main Menu

\subsection{Customer Data Input}

This form is designed to input customer data at PT. Panca Teknik Banjarmasin. Through this form, customer data entry is carried out both customer code, customer name, address. The complete display of the data input form can be seen in the following image

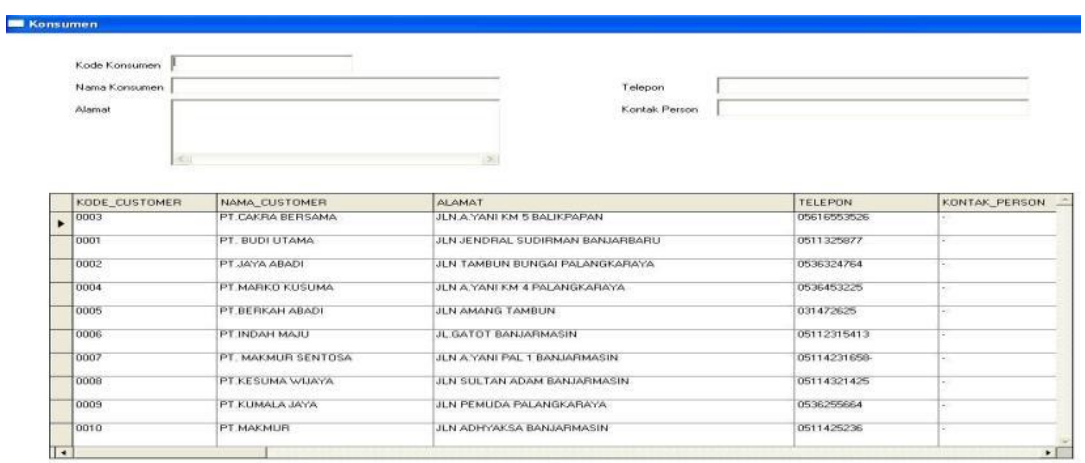

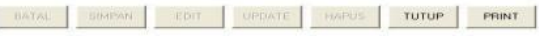

Figure 3. Customer Input 


\section{a. Purchase Data Input}

This form is designed to input purchase data at PT. Panca Teknik Banjarmasin. Through this form the purchase data entry is done either PO number, invoice number, supplier code. The complete display of the data input form can be seen in Figure 4.21 below:

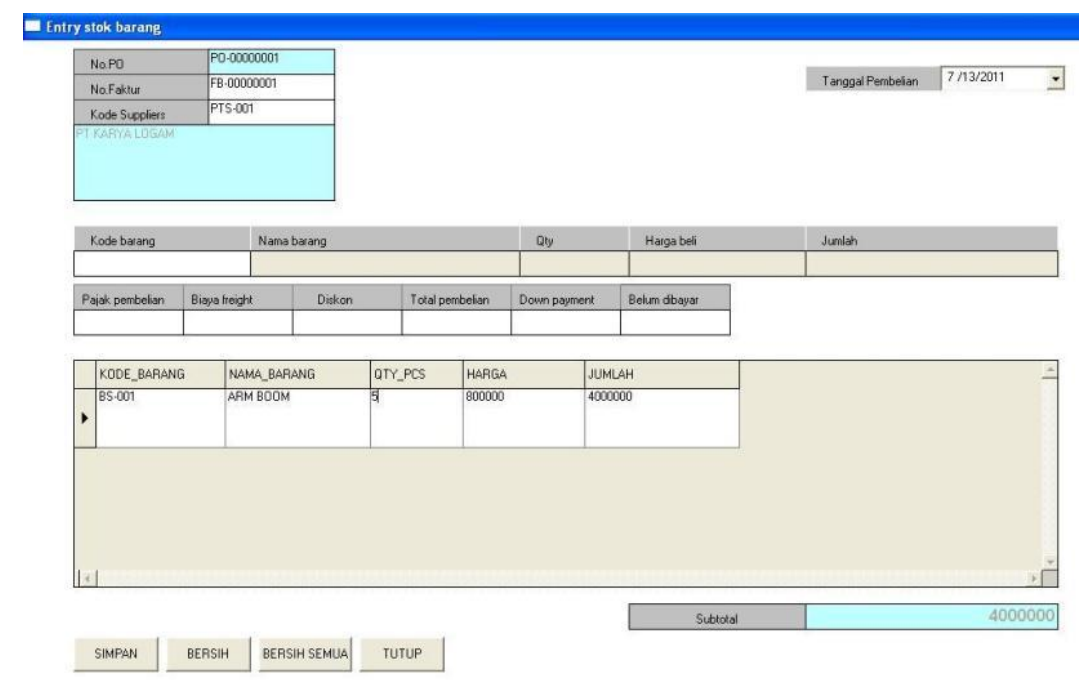

Figure 4. Purchase Input

\section{b. Sales Data Input}

This form is designed to input sales data at PT. Panca Teknik Banjarmasin. Through this form, enter sales data based on order number, invoice number, customer code. The complete display of the data input form can be seen in the following image:

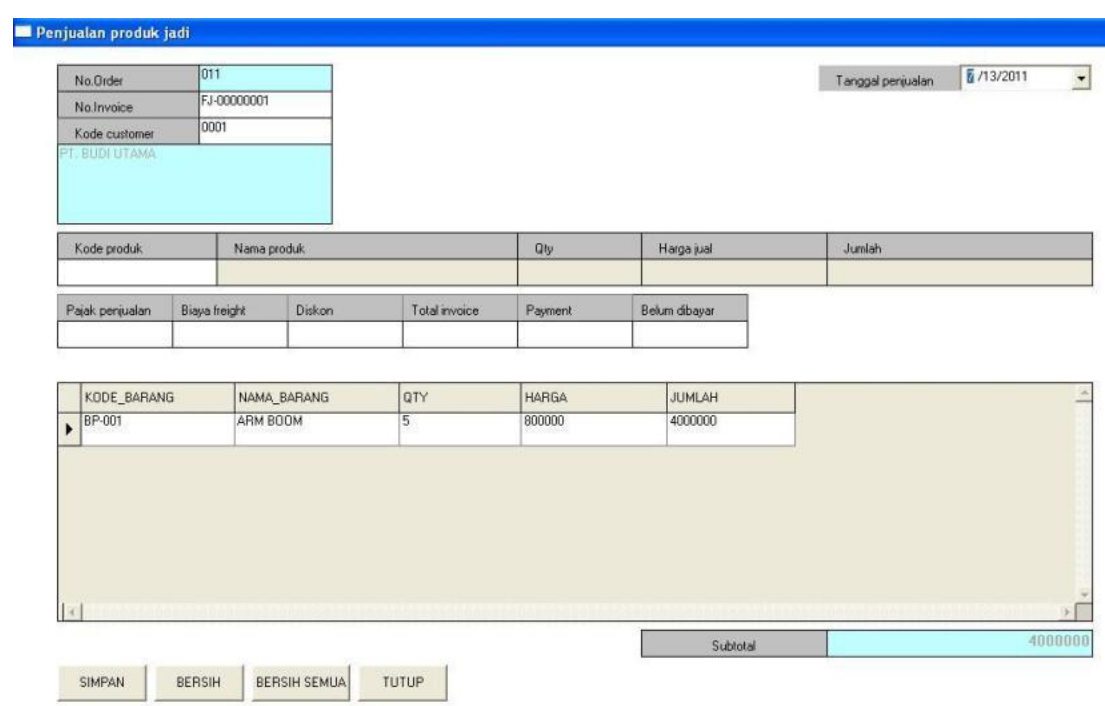

Figure 5. Sales Input

\section{c. Input Stock Items}

This form is designed to input stock data at PT. Panca Teknik Banjarmasin. Through this form, data entry of stock items is based on the item code, name, type, unit. The complete display of the data input form can be seen in the following image 


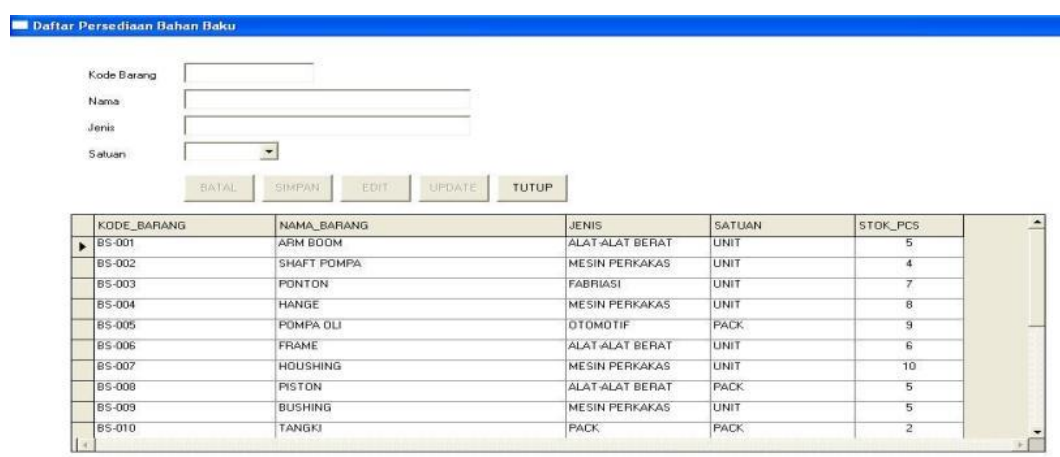

Figure 6. Input Stock Items

\section{d. Production Process Input}

This form is designed to input supplier data at PT. Panca Teknik Banjarmasin. Through this form, supplier data entry is carried out, both supplier code, supplier name, address, telephone, contact person. The complete display of the data input form can be seen in Figure 6 below.

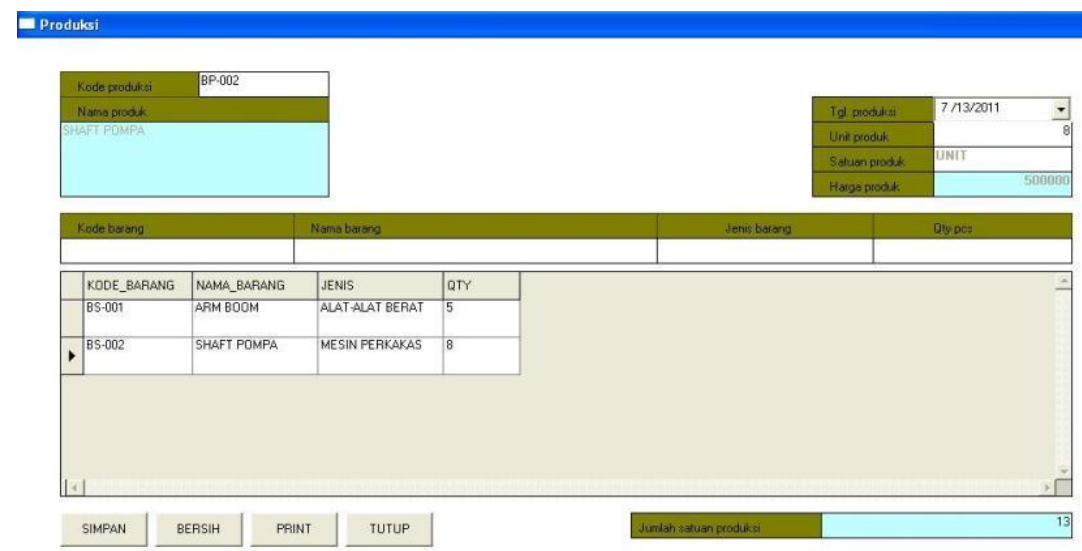

Figure 7. Production Process Input

\section{e. Input Production Results}

This form is designed to input production data at PT. Panca Teknik Banjarmasin. Through this form data entry is carried out both product code, name, type, unit, price. The complete display of the data input form can be seen in the following image

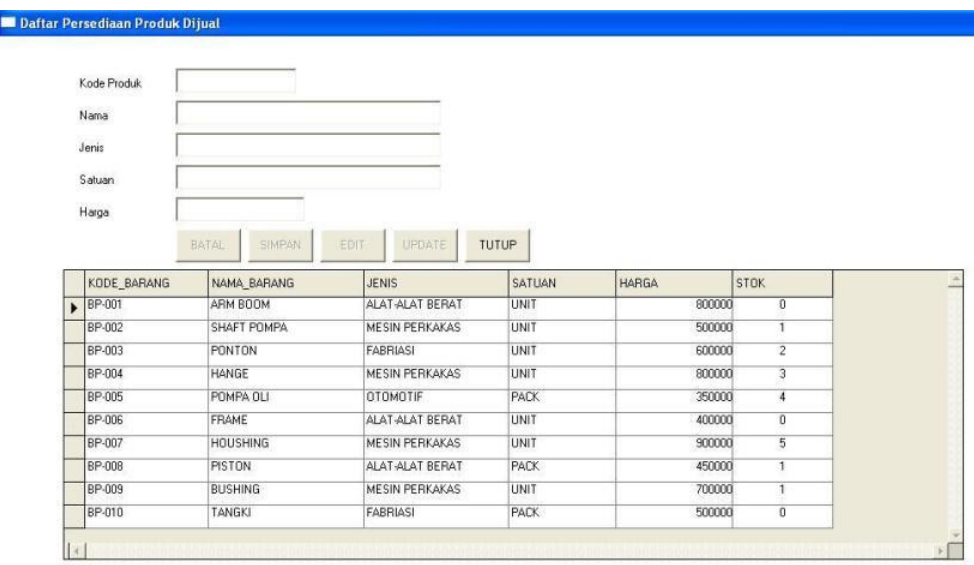

Figure 8.Input Production Results 


\section{f. Supplier Input}

This form is designed to input supplier data at PT. Panca Teknik Banjarmasin. Through this form, supplier data entry is carried out, both supplier code, supplier name, address, telephone, contact person.. The complete display of the data input form can be seen in Figure 5 below:

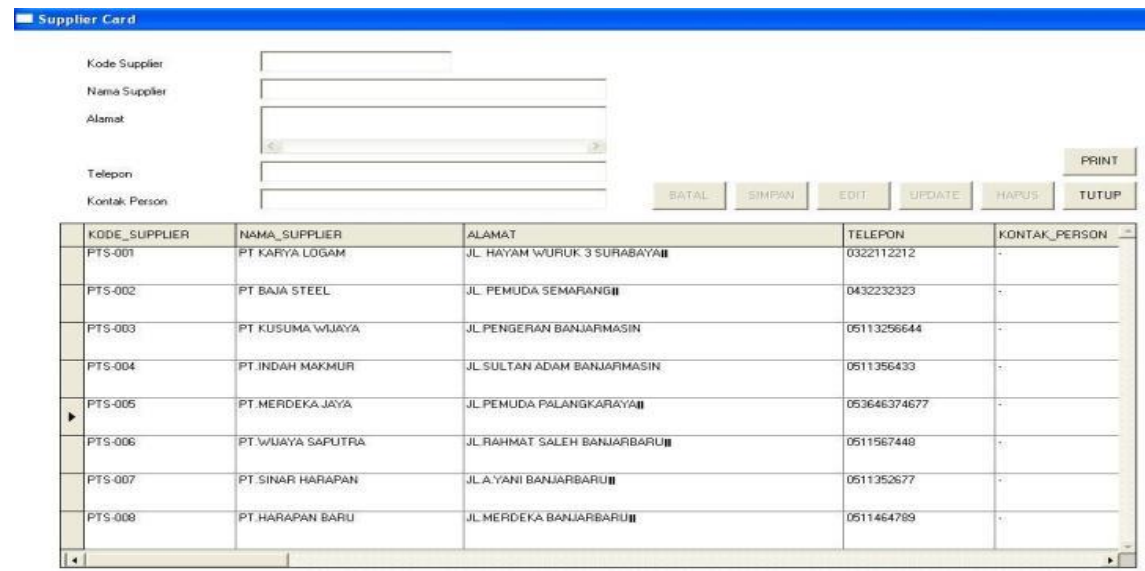

Figure 9. Supplier Input

\section{g. Customer Output}

By using customer output, companies can identify customer data. The following is the output of customer data

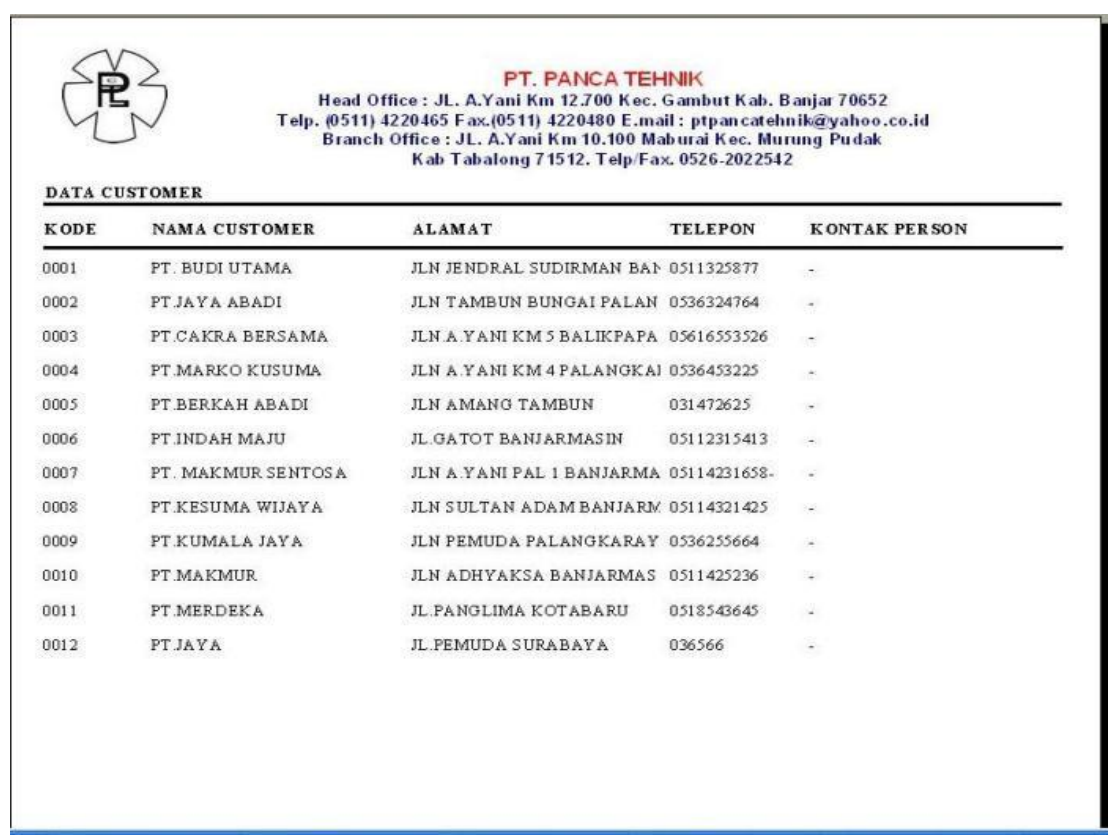

Figure 10. Customer Data Output

\section{h. Sales output}

By using the sales output, companies can identify sales data. The following is the output of the sales data. 


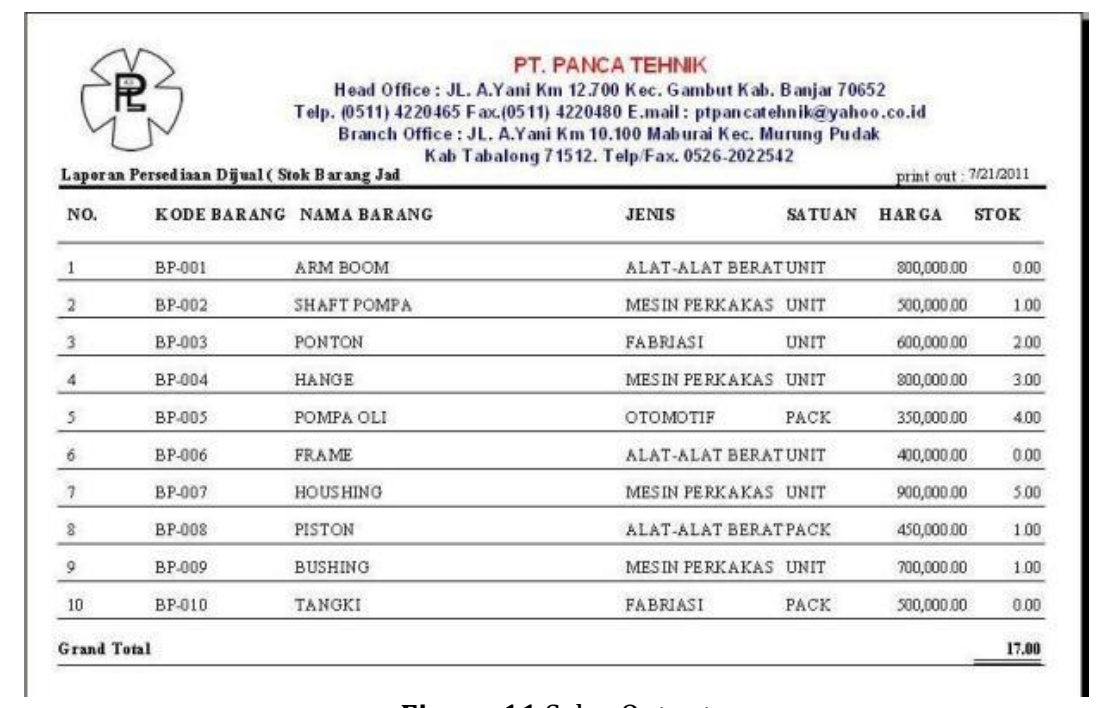

Figure 11.Sales Output

\section{i. Supplier Output}

By using supplier output, companies can identify supplier data. The following is the output of the supplier data.

\begin{tabular}{|c|c|c|c|c|}
\hline \multicolumn{2}{|c|}{ DATA SUPPLIER } & \multicolumn{3}{|c|}{$\begin{array}{c}\text { PT. PANCA TEHNIK } \\
\text { Head Office : JL. A.Yani Km 12.700 Kec. Gambut Kab. Banjar } 70652 \\
\text { elp. (0511) } 4220465 \text { Fax.(0511) } 4220480 \text { E.mail : ptpan catehnikayahoo.co.id } \\
\text { Branch Office : JL. A.Yani Km 10.100 Mab urai Kec. Murung Pudak } \\
\text { Kab Tabalong 71512. Telp Fax. 0526-2022542 }\end{array}$} \\
\hline KODE & NAMA SUPPLIER & ALAMAT & TELEPON & KONTAK PER SON \\
\hline PTS-001 & PT KARYA LOGAM & $\pi$. HAY AM WURUK 3 & 0322112212 & . \\
\hline PTS-002 & PT BAJA STEEL & ЛL. PEMUDA SEMARANG & 0432232323 & . \\
\hline PTS-003 & PT KUSUMA WIJAYA & JL.PENGERAN BANJARMASIN & 05113256644 & - \\
\hline PTS-004 & PT INDAH MAKMUR & תL.SULTAN ADAM BANJARMA & 0511356433 & . \\
\hline PTS-005 & PT MERDEKA JAYA & Л. PEMUDA & 053646374677 & - \\
\hline PTS-006 & PT WIJA YA SAPUTRA & JL.RAHMAT SALEH & 0511567448 & - \\
\hline PTS-003 & PT SINAR HARAPAN & $\pi$.A.YANI BANJARBARU & 0511352677 & - \\
\hline PTS-008 & PT HARAPAN BARU & J.MERDEKA BANJARBARU & 0511464789 & - \\
\hline PTS-009 & PT KEMUNING JAYA & JL.SODARSONO 9 & 043256457 & - \\
\hline PTS-010 & PT BARITO BERSAMA & תL.A.YANI MEDAN & 0345647578 & - \\
\hline PTS-011 & PT BARITO & JLN PEMUDA BANJARMASIN & 0511647657 & . \\
\hline PTS-012 & PT KENCANA & Л.A YANI BANJARMASIN & 051146563 & - \\
\hline
\end{tabular}

Figure 12.Supplier Output

\section{Conclusion}

The conclusion that can be drawn based on the previous chapters is that the design of a databasebased information system using Microsoft Visual Basic can be used as an improvement on the old system that still uses Microsoft Excel. And with this information system can facilitate the company. In making this sales information system program has used relationship design techniques. The design of the system created is intended to help create an application program for processing sales and repair information systems. This sales information system program is used as a guide for employees in doing the work, this certainly makes work easier and shortens the time in doing the work. 


\section{Reference}

Hendrayana, A. (2015). Perencanaan Strategis Teknologi Informasi Guna Meningkatkan Bisnis Perusahaan Menggunakan Pendekatan Ward \& Peppard (Studi Kasus CV. Seribu Satu). Jurnal Wawasan Ilmiah, 7(12).

Maykiyah, S. (2019). Peran pemerintah Kabupaten Seruyan dalam inovasi pengembangan produk hasil perikanan. IAIN Palangka Raya.

Oktavianti, B., \& Rahmawati, H. (2018). Strategi Pemasaran UKM Melalui Program CSR di Perbatasan Kalimantan Utara.

Rahardjo, M. (2017). Studi kasus dalam penelitian kualitatif: konsep dan prosedurnya.

Syahputra, Z. (2015). Penerapan Pemodelan UML Sistem Informasi Perpustakaan Pada Universitas Islam Indragiri Berbasis Client Server. Sistemasi: Jurnal Sistem Informasi, 4(1), 57-64. 